УДК 342.922:340.134

DOI https://doi.org/10.32844/2618-1258.2019.3-1.35

ПІНКЕВИЧ Н.С.

\title{
ОБ'ЄКТ АДМІНІСТРАТИВНО-ПРАВОВОГО РЕГУЛЮВАННЯ У СФЕРІ ПОВОДЖЕННЯ З ВІДХОДАМИ
}

\begin{abstract}
У статті досліджено питання адміністративно-правового регулювання у сфері поводження з відходами. На основі проведеного аналізу визначено, що основна регулювальна роль в адміністративно-правовому регулюванні у сфері поводження 3 відходами належить нормам екологічного та адміністративного права. У контексті правового регулювання у сфері поводження з відходами розглядаються поняття «адміністративно-правове регулювання», «об'єкт регулювання». Виокремлено й досліджено поняття «поводження з відходами». Установлено, що законодавство України має кілька визначень поняття «поводження з відходами»: 1) дії щодо запобігання утворенню, збиранню, транспортуванню, сортуванню, зберіганню, обробці, переробці, утилізації, видаленню, нейтралізації та захороненню, у т. ч. контроль цих операцій й нагляд за місцями захоронення; поводження з відходами визначається як збирання, транспортування, зберігання, утилізація й утилізація відходів, включаючи подальший моніторинг місць утилізації/захоронення; 2) збирання, транспортування, зберігання, утилізація й утилізація відходів, включаючи подальший контроль за місцями утилізації/захоронення; 3) збирання, транспортування, зберігання, обробка, утилізація відходів, включаючи контроль за цими операціями та нагляд за місцями утилізації/захоронення; 4) заходи, спрямовані на запобігання утворенню відходів, збирання, транспортування, зберігання, обробку, утилізацію, знешкодження, знешкодження та вивезення, включаючи контроль за цими операціями й нагляд за місцями захоронення. Узагальнено, що закон позначає «поводження з відходами» як запобігання утворенню відходів, тоді як регламент - лише прямі дії з поводження з відходами - збирання, транспортування, сортування, зберігання, обробку, переробку, використання, видалення, знешкодження, включаючи контроль за цими операціями й нагляд за місцями захоронення.
\end{abstract}

Проаналізовано основні поняття у сфері поводження з відходами: «збирання відходів», «розподіл відходів», «поводження з відходами» тощо. Ураховуючи це, уточнюється, що об'єктом адміністративно-правового регулювання у сфері поводження з відходами є правовідносини, що виникають у зв'язку із: 1) запобіганням відходів (у разі здійснення заходів, що вживаються до того, як речовина, матеріал чи продукт стають відходами: а) кількість відходів, у тому числі утворених після переробки продукції або продовження життєвого циклу продукції; б) несприятливий вплив відходів на довкілля та здоров'я людини; в) уміст шкідливих речовин у матеріалах і продуктах); 2) поводження з відходами (збирання, транспортування, сортування, зберігання, утилізація, обробка (переробка), вивезення, знешкодження, контроль за цими операціями й обслуговування місць видалення відходів).

Ключові слова: відходи, поводження з відходами, утилізаиія, вторинна сировина, законодавство, об'єкт адміністративно-правового регулювання.

The article investigates the issues of administrative and legal regulation in the field of waste management. On the basis of the analysis it is defined that the basic regulating role in administrative-legal regulation in the sphere of waste management belongs to norms of ecological and administrative law. In the context of legal regulation in the sphere of waste management the concepts of "administrative and legal regulation", "object of regulation" are considered. The concept of "waste management" is singled out and

(C) ПІНКЕВИЧ Н.С. - здобувач (Державний науково-дослідний інститут Міністерства внутрішніх справ України) 
investigated. It has been established that the legislation of Ukraine has several definitions of the concept of "waste management": 1) actions for preventing waste generation, collection, transportation, sorting, storage, treatment, recycling, utilization, removal, neutralization and disposal, including control of these operations and supervision of disposal sites; waste management is defined as collection, transportation, storage, utilization and disposal of waste, including subsequent monitoring of utilization/disposal sites; 2) collection, transportation, storage, utilization and disposal of waste, including subsequent control over utilization/disposal sites; 3) collection, transportation, storage, treatment, utilization and disposal of waste, including control over these operations and supervising utilization/disposal sites; 4) actions aimed at prevention of waste generation, collection, transportation, storage, treatment, utilization, disposal, neutralization and removal, including control of these operations and supervision of disposal sites. It is summarized that the law refers to "waste management" as the prevention of waste generation, while the regulations - only direct waste management actions - collection, transportation, sorting, storage, processing, treatment, recycling, utilization, removal, neutralization and disposal, including control over these operations and supervision of disposal sites.

The basic concepts in the sphere of waste management are analyzed: "waste collection", "waste distribution", "waste management" and others. With this as a background, it is specified that the object of administrative-legal regulation in the sphere of waste management is the legal relations arising from: 1) waste prevention (in case of implementation of measures taken before the substance, material or product becomes a waste, reduce: a) the amount of waste, including those formed after processing of products or prolongation of the life cycle of products; b) adverse impact of waste on the environment and human health; c) content of harmful substances in materials and products); 2) waste management (collection, transportation, sorting, storage, utilization, treatment (recycling), removal, disposing, control over these operations and maintenance of waste disposal sites).

Key words: waste, waste management, utilization, secondary raw materials, legislation, object of administrative and legal regulation.

Вступ. У Концепції Загальнодержавної програми поводження з відходами на 20132030 роки, затвердженій Кабінетом Міністрів України, від 3 січня 2013 року № 22-р визнається кризова ситуація, пов'язана з відходами, що утворилася в Україні сьогодні [1]. За офіційними даними, в країні накопичено близько 36 млрд. тонн відходів, або більше як 50 тис. тонн на 1 кв. кілометр території, з яких утилізується лише $30 \%$ промислових відходів і 4\% побутових відходів [1].

Аналіз правового регулювання у сфері поводження з відходами переконує, що основну регулювальну роль у цій сфері відіграють норми екологічного права, проте не остання роль належить нормам адміністративного права, оскільки вони врегульовують відносини у сфері управління поводження з відходами органами публічного адміністрування, адміністративної відповідальності й інших публічних відносин у сфері поводження з відходами тощо. О.М. Гаврилюк підкреслює, що серед значної кількості галузей права, нормами яких регулюються суспільні відносини у сфері поводження з відходами, важливу роль відіграють норми адміністративного права [2], а В.К. Колпаков відзначає, що «проникнення» адміністративного права у сфери інших галузей права зумовлюється наявністю управлінських відносин у предметі тієї чи іншої галузі права, а адміністративне право охоплює своїм регулятивним впливом надзвичайно широке коло суспільних відносин управлінського типу.

Постановка завдання. Отже, метою дослідження є визначення об’єкта адміністративно-правового регулювання у сфері поводження з відходами.

Результати дослідження. Адміністративно-правове регулювання широко вивчено в науці адміністративного права. В.І. Олефір, Ю.В. Гридасов, А.А. Іванищук, С.О. Короєд писали, що адміністративно-правове регулювання - це цілеспрямований вплив норм адміністративного права на суспільні відносини з метою забезпечення за допомогою адміністративно-правових засобів прав, свобод і законних інтересів фізичних і юридичних осіб, нормального функціонування громадянського суспільства й держави [3, с. 245]. П.М. Павлик зазначає, що адміністративно-правове регулювання - це особливий вид правового регулювання, специфічність якого визначається 
об'єктом впливу, тобто відносинами, що регулюються адміністративним правом і зумовлені особливостями його норм [4, с. 189]. Н.В. Галіцина робить висновок, що адміністративно-правове регулювання як різновид державного регулювання $\epsilon$ механізмом імперативного-нормативного упорядкування організації й діяльності суб'єктів та об'єктів управління й формування стійкого правового порядку їх функціонування [5, с. 9].

На думку В.В. Галунько, Г.О. Пономаренко, В.К. Шкарупи, А.М. Чорної, адміністративно-правове регулювання $є$ спеціальним юридичним механізмом впливу адміністративного права на поведінку й діяльність його суб'єктів та об'єктів. Унаслідок адміністративно-правової регламентації формується юридична основа, визначаються зафіксовані в правових веліннях орієнтири для організації діяльності учасників адміністративно-правових відносин на досягнення фактичних завдань адміністративного права [6, с. 113-114; 7]. О.П. Рябченко вважає, що адміністративно-правове регулювання - це діяльність, яка складається з послідовно змінюваних одна одну в певному порядку дій, а регулювання протікає за певною процедурою, яка також розглядається як форма щодо змісту цієї діяльності [8, с. 81-84]. І.М. Миронець, Д.С. Андрєєва, К.В. Шустрова вказують, що найбільш поширеним $є$ трактування адміністративно-правового регулювання як цілеспрямованого, упорядковувального, управлінського впливу держави на суспільні відносини [6, c. 113-114].

Незважаючи на певні розбіжності, науковці загалом досягають згоди в тому, що адміністративно-правове регулювання являє собою спеціальний цілеспрямований, упорядкований, управлінський вплив на суспільні відносини за допомогою норм адміністративного права 3 метою забезпечення прав, свобод і законних інтересів фізичних і юридичних осіб, нормального функціонування громадянського суспільства й держави, який здійснюється різноманітними суб'єктами адміністративного права.

За правильним визначенням А.М. Чорної, як і будь-який вид правового регулювання, адміністративно-правове регулювання має свій об'єкт [7].

Об'єкт (лат. objectum - «предмет») - предмет, явище, на які спрямована певна діяльність людини [9, с. 287]. У філософському розумінні об'єктом є матеріальний предмет пізнання і впливу $з$ боку людини (суб'єкта), який існує поза нами й незалежно від нашої свідомості [10]. Об'єктом визначається також те, на що спрямована діяльність дослідника, процес або явище, що породжує проблемну ситуацію й обране для дослідження [11].

До питання об'єкта адміністративно-правового регулювання зверталися в роботах В.Б. Авер'янов, О.М. Бандурка, Ю.П. Битяк, В.В. Галунько, О.Т. Коломієць, А.М. Колодій, В.В. Копейчиков, Л.І. Миськів, Л.А. Черниш та інші. Більшість науковців доходить згоди, що об'єктом адміністративно-правового регулювання є об'єкт адміністративних правовідносин $[2 ; 12$, c. $245 ; 13$, c. 98$]$.

Правовідносинами в теорії права $є$ врегульовані нормами права суспільні відносини, учасники яких виступають як носії взаємних суб'єктивних прав і юридичних обов'язків, що забезпечуються державою [13, с. 98]; урегульовані нормами права вольові суспільні відносини, які виражаються в конкретному взаємозв'язку між уповноважувальними й зобов'язальними суб' $є к-$ тами - носіями суб'єктивних юридичних прав, обов'язків, повноважень і відповідальності, та забезпечувані державою [12, с. 256]. Визначаючи об'єкт адміністративно-правових відносин, необхідно розуміти, на що спрямовані інтереси суб'єктів, з приводу чого останні вступають в адміністративно-правові відносини, оскільки між цими елементами існує нерозривний зв'язок [2; 12, с. 245]. Г.Г. Забарний, Р.А. Калюжний, В.О. Терещук, В.К. Шкарупа вважають, що об'єктом адміністративно-правових відносин є суспільні відносини, що уособлюють характер діяльності окремих суб'єктів права, юридичні наслідки їхньої поведінки, певні правові інтереси, зокрема майнового чи немайнового характеру, тощо [2; 14, с. 20]. Т.О. Коломоєць, Н.О. Армаш та інші пишуть, що об'єктами адміністративних правовідносин є матеріальні й нематеріальні блага, які становлять публічну цінність, і діяння суб'єктів та об'єктів публічного управління, пов'язані із цими благами $[2 ; 15$, с. 198$]$.

Отже, для визначення об’єкта адміністративно-правового регулювання у сфері поводження з відходами, необхідно дослідити, які правовідносини у сфері поводження з відходами врегульовуються адміністративно-правовими нормами. При цьому необхідно пам'ятати, що до особливостей адміністративно-правових норм належить такі: 1) закріплення в них відносин щодо управління, державного контролю, нагляду, внутрішньоорганізаційної діяльності; 2) метод впливу на суспільні відносини має імперативний, державно-владний характер; 3) виконання приписів норм гарантується державою за допомогою системи засобів організаційно-роз'яснювального й 
суспільно-примусового характеру [16, с. 46]. Для цього нам необхідно проаналізувати поняття «поводження з відходами».

Відповідно до статті 1 Закону про відходи, поводження з відходами являють собою дії, спрямовані на запобігання утворенню відходів, їх збирання, перевезення, сортування, зберігання, оброблення, перероблення, утилізацію, видалення, знешкодження й захоронення, включаючи контроль за цими операціями та нагляд за місцями видалення [17].

Проте це не єдине визначення поводження з відходами, закріплене в національному законодавстві. У Постанові Кабінету Міністрів України «Про впорядкування контролю за транскордонним перевезенням відходів та їх утилізацією/видаленням» від 12 вересня 1997 року № 1016, поводження з відходами визначається як збирання, перевезення, зберігання, утилізація й видалення відходів, включаючи подальший контроль за місцями утилізації/видалення [18]. Згідно з Положенням про контроль за транскордонними перевезеннями небезпечних відходів та їх утилізацією/ видаленням і Жовтого та Зеленого переліків відходів від 13 липня 2000 року № 1120, поводження 3 відходами являє собою збирання, перевезення, зберігання, оброблення, утилізацію й видалення відходів, включаючи контроль за цими операціями та нагляд за місцями утилізації/видалення [19]. Відповідно до Технічного регламенту з підтвердження відповідності пакування (пакувальних матеріалів) та відходів пакування, затвердженого Наказом Держспоживстандарту України від 24 грудня 2004 року, поводження з відходами - це дії, спрямовані на запобігання утворенню відходів, їх збирання, перевезення, зберігання, оброблення, утилізацію, видалення, знешкодження й захоронення, включаючи контроль за цими операціями та нагляд за місцями видалення [20].

Виходячи із цього, констатуємо, що до поводження з відходами українське законодавство зараховує дії, спрямовані на запобігання утворенню відходів, тоді як підзаконні акти про поводження з відходами зараховують до цієї категорії лише безпосередні дії щодо поводження з відходами - збирання, перевезення, сортування, зберігання, оброблення, перероблення, утилізацію, видалення, знешкодження й захоронення, включаючи контроль за цими операціями та нагляд за місцями видалення. Аналогічним чином закріплюється поняття поводження з відходами й в інших нормативно-правових документах у цій сфері [19].

До основних аспектів, що визначають поняття «поводження з відходами», належить запобігання утворенню відходів. Поняття «запобігання утворенню відходів» законодавство України не розкриває, хоча в статті 31 Закону про відходи передбачаються заходи щодо запобігання або зменшення обсягів утворення відходів і стимулювання впровадження маловідходних технологій, обмеження негативного впливу та запобігання негативному впливу відходів на навколишнє природне середовище і здоров'я людини [17], що ситуацію це не вирішує.

Відсутність одного з важливих термінів - запобігання утворенню відходів, що визначає основи поводження з відходами, $є$ суттєвою прогалиною вітчизняного законодавства, на що звертала увагу в роботі Т.Л. Антонова, яка пропонувала визначати запобігання утворенню відходів як здійснення комплексу заходів, які вжиті до того, як речовина, матеріал або продукт перетворюється на сміття, завдяки яким знижується кількість відходів, виключно з повторним використанням продуктів або продовження терміну використання продуктів; небажаний вплив утворених відходів на навколишнє природне середовище та здоров'я людини або вміст шкідливих речовин у матеріалах і продуктах [21]. Цілком погоджуючись із позицією авторки щодо необхідності усунення прогалини Закону про відходи стосовно визначення поняття «запобігання утворенню відходів», зазначимо, що в національному законодавстві доцільно вжити визначення, викладене в Директиві Європейського Парламенту й Ради Свропейського Співтовариства 2008/98/EC (англ. Directive 2008/98/EC of the European Parliament and of the Council of 19 November 2008 on waste and repealing certain Directives) (далі - Директива 2008/98/EC) [22], яка є рамковою директивою поводження з відходами в СС.

Адміністративно-правовими нормами у сфері запобігання утворенню відходів урегульовуються відносини, що виникають під час здійснення заходів, ужитих перед тим, як речовина, матеріал або продукт стане відходами, що зменшують: а) кількість відходів, включаючи ті, що утворені після переробки продуктів чи продовження життєвого циклу продуктів; б) несприятливий вплив відходів на довкілля та здоров’я людини; в) уміст шкідливих речовин у матеріалах і продуктах.

Порядок поводження з відходами, що утворилися, розкривається в Законі про відходи через категорії «операції з поводження з відходами», до яких належить збирання, перевезення, зберігання, сортування, оброблення (перероблення), утилізація, видалення, знешкодження й захоронення відходів [17]. 
Збирання відходів у статті 1 Закону про відходи визначається як діяльність, пов'язана 3 вилученням, накопиченням і розміщенням відходів у спеціально відведених місцях чи об'єктах, включаючи сортування відходів з метою подальшої утилізації чи видалення [17]. Згідно з Державними санітарними правилами та нормами. 2. Комунальна гігієна. 2.7. Грунт, очистка населених місць, побутові та промислові відходи, санітарна охорона грунту. «Гігієнічні вимоги щодо поводження з промисловими відходами та визначення їх класу небезпеки для здоров'я населення». ДСанПіН 2.2.7.029-99», затвердженими Наказом Головного санітарного лікаря України від 1 липня 1999 року № 29, збиранням відходів є діяльність, що пов’язана з вилученням, накопиченням і розміщенням відходів у спеціально відведених місцях чи на об’єктах і включає сортування відходів з метою подальшої утилізації чи видалення [23].

У Директиві 2008/98/ЄС термін «збирання» не застосовується, замість нього використовується поняття «збір» та «роздільний збір» (ст. 3.10). Збором, згідно з нормами зазначеної Директиви, $є$ збирання відходів, включаючи первісне сортування та початкове зберігання відходів 3 метою транспортування до закладу обробки відходів, а роздільним збором - збирання, коли потік відходів іде окремо за видом і природою, полегшуючи специфічну обробку [22].

Не вдаючись до полеміки стосовно співвідношення слів «збирання» та «збір», оскільки, відповідно до Академічного словника української мови, збирання являє собою: 1) дії за значенням збирати, збиратися; 2) те саме, що збиральництво, а збір - 1) дія за значенням збирати; 2) дія за значенням збирати, збиратися; 3) нагромадження чого-небудь завдяки поступовому збиранню; 4) сума грошей, зібраних з багатьох людей, з багатьох джерел [24], зосередимо увагу на співвідношенні термінів, закріплених у національному та європейському законодавствах.

Головною відмінністю у визначенні збирання відходів $є$ мета їх збирання: в України такою метою є подальша утилізація чи видалення, а в СС - транспортування до закладу обробки відходів. Подібне визначення впливає на правовий режим та обов'язки власника відходів. Ураховуючи зазначене, вважаємо доцільним визначення «збирання відходів» у національному законодавстві уніфікувати й викласти відповідно до європейського законодавства.

Необхідно звернути увагу й на визначення «роздільний збір», яке в національному законодавстві не закріплене. Відповідно до статті 3.11 Директиви 2008/98/ЄС, як уже зазначалося, роздільним збором є збирання, коли потік відходів іде окремо за видом і природою, щоб полегшити специфічну обробку [22]. Відсутність чітко визначеного терміна «роздільний збір» у національному законодавстві створює значні проблеми. Наприклад, у Національній стратегії управління відходами в Україні до 2030 року передбачається низка заходів, спрямованих на створення системи роздільного збирання відходів (залучення населення до роздільного збирання побутових відходів і стимулювання такого їх збирання, збільшення охоплення населення послугами збирання та вивезення побутових відходів з подальшим поширенням послуг у селищах і селах, роздільного збирання та зберігання відходів упаковки, встановлення вимог до маркування електричного й електронного обладнання для полегшення процесу роздільного збирання й запобігання його потраплянню до несортованих твердих побутових відходів, роздільне збирання відходів електричного та електронного обладнання, обробку й утилізацію/відновлення роздільно зібраних відходів електричного та електронного обладнання, створення власних пунктів збирання відходів електричного та електронного обладнання, де буде організовано прийом різних фракцій роздільно зібраних відходів електричного та електронного обладнання, зобов'язання виробників щодо забезпечення поводження з відпрацьованими батарейками, батареями й акумуляторами, які включають роздільне збирання відпрацьованих батарейок, батарей та акумуляторів; перероблення роздільно зібраних відпрацьованих батарейок, батарей та акумуляторів тощо), при цьому в законодавстві навіть не визначено, що являє собою роздільне збирання доходів. Тому є нагальна необхідність закріплення визначення поняття «роздільний збір» у вітчизняному законодавстві в редакції, викладеній у Директиві 2008/98/СС [22].

Визначення понять «перевезення», «сортування», «зберігання», «утилізація», «оброблення (перероблення)», «видалення», «захоронення» в контексті поняття «відходів» міститься в статті 1 Закону про відходи, де «перевезення» визначається як транспортування відходів від місць їх утворення або зберігання до місць чи об'єктів оброблення, утилізації чи видалення; «сортування» - як механічний розподіл відходів за їх фізико-хімічними властивостями, технічними складниками, енергетичною цінністю, товарними показниками тощо 3 метою підготовки відходів до їх утилізації чи видалення; «зберігання» - як тимчасове розміщення відходів у спеціально відведених місцях чи об'єктах (до їх утилізації чи видалення); «утилізація» - як використання відходів як вторинних матеріальних чи енергетичних ресурсів; «оброблення (перероблен- 
ня)»-як здійснення будь-яких технологічних операцій, пов'язаних зі зміною фізичних, хімічних чи біологічних властивостей відходів 3 метою підготовки їх до екологічно безпечного зберігання, перевезення, утилізації чи видалення; «видалення» - як здійснення операцій з відходами, що не призводять до їх утилізації; «знешкодження» - як зменшення чи усунення небезпечності відходів шляхом механічного, фізико-хімічного чи біологічного оброблення; «захоронення» - як остаточне розміщення відходів при їх видаленні в спеціально відведених місцях чи на об'єктах так, щоб довгостроковий шкідливий вплив відходів на навколишнє природне середовище та здоров'я людини не перевищував установлених нормативів [17].

У Директиві 2008/98/ЄС усі вищеперераховані операції визначаються як «управління відходами» (ст. 3.9), а саме «управління відходами - збір, перевезення, утилізація та ліквідація відходів, включаючи нагляд за цими операціями та догляд за місцями захоронення відходів, включаючи дії брокерів чи дилерів» [17]. Уважаємо за доцільне запровадити цей термін і в національне законодавство шляхом унесення змін до статті 1 Закону про відходи.

Поняття «контроль за поводженням з відходами та нагляд за місцями видалення» національне законодавство не визначає, проте, згідно з п. «е» Закону про відходи, до повноважень Автономної Республіки Крим у сфері поводження з відходами належить контроль за виконанням на території Автономної Республіки Крим загальнодержавних програм і програм поводження з відходами, а відповідно до п. «ж» - контроль за дотриманням законодавства підприємствами, установами, організаціями та громадянами, які здійснюють діяльність у сфері поводження з відходами на території Автономної Республіки Крим [17]. Крім цього, згідно з п. «г» статті 21 цього ж Закону, до повноважень органів місцевого самоврядування належить затвердження місцевих і регіональних програм поводження з відходами та контроль за їх виконанням, а в статті 37 визначається, що контроль у сфері поводження з відходами здійснюють центральний орган виконавчої влади, що реалізує державну політику зі здійснення державного нагляду (контролю) у сфері охорони навколишнього природного середовища, раціонального використання, відтворення й охорони природних ресурсів, центральний орган виконавчої влади, що реалізує державну політику у сфері санітарного та епідемічного благополуччя населення, місцеві державні адміністрації, виконавчі органи сільських, селищних, міських рад, громадські інспектори з благоустрою населених пунктів [17]. Отже, контроль у сфері поводження з відходами являє собою діяльність відповідних суб'єктів із забезпечення нагляду за дотриманням установлених законодавством вимог у сфері поводження з відходами.

Аналіз терміна «управління відходами», закріпленого в Директиві 2008/98/СС, переконує, що контроль у сфері поводження з відходами охоплюється вищевказаним поняттям. Адміністративно-правовим нормами у сфері управління з відходами врегульовуються відносини щодо управління відходами (іх збирання, перевезення, сортування, зберігання, утилізація, оброблення (перероблення), видалення, захоронення, а також контроль за цими операціями та догляд за місцями захоронень відходів).

Висновки. Отже, об’єктом адміністративно-правового регулювання у сфері поводження 3 відходами є правовідносини, що виникають щодо:

- запобігання утворенню відходів (під час здійснення заходів, ужитих перед тим, як речовина, матеріал або продукт стане відходами, що зменшують: а) кількість відходів, включаючи ті, що утворені після переробки продуктів чи продовження життєвого циклу продуктів; б) несприятливий вплив відходів на довкілля та здоров'я людини; в) уміст шкідливих речовин у матеріалах і продуктах);

- управління відходами (іх збирання, перевезення, сортування, зберігання, утилізації, оброблення (перероблення), видалення, захоронення, контролю за цими операціями та догляд за місцями захоронень відходів).

\section{Список використаних джерел:}

1. Про схвалення Концепції Загальнодержавної програми поводження 3 відходами на 2013-2020 роки : Розпорядження Кабінету Міністрів України від 3 січня 2013 р. № 22-р.

2. Гаврилюк О.М. Адміністративно-правове регулювання поводження з побутовими відходами : дис. ... канд. юрид. наук : 12.00.07 / НДІ публіч. права. Київ, 2017. 206 с.

3. Адміністративне право України : підручник : у 2 т. Херсон, 2013. Т. 1 : Загальне адміністративне право. Академічний курс / В.В. Галунько, В.І. Олефір, Ю.В. Гридасов, А.А. Іванищук, С.О. Короєд ; Відкритий міжнар. ун-т розв. людини «Україна». 393 с.

4. Адміністративно-правове забезпечення прав і свобод людини та громадянина: навчальний посібник / I.О. Ієрусалімова, I.О. Ієрусалімов, П.М. Павлик, Ж.В. Удовенко. Київ : Знання, 2007. $223 \mathrm{c}$. 
5. Адміністративно-правові засади процедури створення та функціонування товариств 3 обмеженою відповідальністю в Україні : автореф. дис. ... канд. юрид. наук : 12.00.07 / Класич. приват. ун-т. Запоріжжя, 2010. 20 с.

6. Галунько В.В., Пономаренко Г.О., Шкарупа В.К. Теорія держави і права : навчальний посібник. Херсон : ВАТ «ХМД», 2010. 280 с.

7. Чорна А. Підприємницька діяльність як об'єкт адміністративно-правового регулювання. Підприємниитво, господарство і право. 2017. № 5. С. 128-132.

8. Рябченко О. Зміст державного регулювання господарської діяльності. Право Украӥни. 2006. № 1. С. 81-84.

9. Юридична енциклопедія : у 6 т. / редкол. : Ю.С. Шемшученко (відп. ред.) та ін. Київ : Укр. енцикл., 2001. Т. 3 : П-С. 736 с.

10. Словник іншомовних слів / за редакцією члена-кореспондента АН УРСР О.С. Мельничука. 1-е вид. Київ : Головна редакція «Українська радянська енциклопедія» (УРЕ), 1974. 776 с.

11. Довідник здобувача наукового ступеня: 36. нормат. док. та 58 інформ. матеріалів 3 питань атестації наук, кадрів вищої кваліфікації / упоряд. Ю.І. Цеков ; передмова до 3-го, 2-го і 3 переднього сл. до 1-го вид. Р.В. Бойка. 3-тє вид., випр. і допов. Київ: Ред. «Бюл. Вищої атестац. коміс. України»; Толока, 2004. 69 с.

12. Адміністративне право України : академічний курс / В.Б. Авер'янов та ін. ; відп. ред. В.Б. Авер'янов ; НАН України, Інститут держави і права ім. В.М. Корецького. Київ : Юридична думка, 2007. Т. 1 : Загальна частина. Київ : Б. м. : б.в., 2007. 591 с.

13. Правознавство : підручник / А.І. Берлач, Д.О. Карпенко, В.С. Ковальський, А.М. Колодій, А.Ю. Олійник, О.О. Підопригора ; за ред. В.В. Копєйчикова, А.М. Колодія. Київ : Юрінком Інтер, 2004. $-752 \mathrm{c}$.

14. Забарний Г.Г., Калюжний Р.А., Шкарупа В.К. Адміністративне право України : навчальний посібник. Київ : Вид. ПАЛИВОДА А.В., 2005. 368 с.

15. Адміністративне право : підручник / Т.О. Коломоєць, Н.О. Армаш та ін. ; за заг. ред. Т.О. Коломоєць. Київ : Істина, 2010. 362 с.

16. Адміністративне право: загальна частина : навчальний посібник / С.М. Алфьоров, С.В. Ващенко, М.М. Долгополова, А.П. Купін. Київ : Центр учбової літератури, 2011. 216 с.

17. Про відходи : Закон України від 5 березня 1998 p. № 187/98-VR. URL: https://zakon. rada.gov.ua/laws/main/187/98-\%D0\%B2\%D1\%80.

18. Про впорядкування контролю за транскордонним перевезенням відходів і їх утилізацією/видаленням : Постанова Кабінету Міністрів України від 12 вересня 1997 р. № 1016 URL: https://zakon.rada.gov.ua/laws/main/1016-97-\%D0\%BF.

19. Про затвердження Положення про контроль за транскордонними перевезеннями небезпечних відходів та їх утилізацією/видаленням і Жовтого та Зеленого переліків відходів : Постанова Кабінету Міністрів України від 13 липня 2000 р. № 1120. URL: https://zakon.rada.gov.ua/ laws/main/1120-2000-\%D0\%BF.

20. Про затвердження Технічного регламенту з підтвердження відповідності паковання (пакувальних матеріалів) та відходів паковання : Наказ Державного комітету України $з$ питань технічного регулювання та споживчої політики від 24 грудня 2004 р. № 289. URL: https://zakon. rada.gov.ua/laws/main/z0095-05.

21. Антонова Т.Л. Загальна характеристика операцій поводження з відходами в Україні. Науковий вісник Міжнародного гуманітарного університету. Серія «Юриспрудениія». 2017. Вип. 25. С. 26-29.

22. Directive 2008/98/EC of the European Parliament and of the Council of 19 November 2008 on waste and repealing certain Directives (Text with EEA relevance). URL: https://eur-lex.europa.eu/ eli/dir/2008/98/2018-07-05.

23. Про затвердження «ДЕРЖАВНІ САНІТАРНІ ПРАВИЛА ТА НОРМИ 2. Комунальна гігієна. 2.7. Грунт, очистка населених місць, побутові та промислові відходи, санітарна охорона грунту. «Гігієнічні вимоги щодо поводження з промисловими відходами та визначення їх класу небезпеки для здоров'я населення» ДСанПіН 2.2.7.029-99 : Постанова Головного державного санітарного лікаря України від 1 липня 1999 р. № 29. URL: https://zakon.rada.gov.ua/rada/show/ v0029588-99?lang=ru.

24. Словник української мови : в 11 т. / АН Української РСР, Ін-т мовознавства ім. О.О. Потебні ; редкол. : І.К. Білодід (голова) та ін. Київ : Наукова думка, 1970. 1980. 